Chapter 15

\title{
Acute Psychiatric Trauma Intervention - The January 2010 Haiti Earthquake
}

\author{
Kent Ravenscroft \\ Additional information is available at the end of the chapter \\ http://dx.doi.org/10.5772/59867
}

\section{Introduction}

Much is written about disaster psychiatry, all essential reading for anyone volunteering to do this kind work. Much less is written about what it is actually like to do trauma work on the ground, often under dire circumstances. How do you actually apply this important body of psychiatric knowledge to traumatized patients and families? And do it when you yourself are anxious, tired, and pushed to the limit? How do you manage your own health and mental health while working in the trenches alongside equally stressed colleagues struggling with flooded clinics, minimal equipment and short supplies? How do you keep your head screwed on straight when the work itself is traumatizing, and the circumstances crazy making? How do you cope as you question your clinical skills and competence, your judgment calls, and your ethical standards at every turn with the circumstances constantly fluctuating? All this happens despite the best efforts of whatever NGO (non-governmental organization) you're working with.

This chapter is about the Haiti earthquake, a disaster of unimaginable proportions. It is about the experience of one psychiatrist, a volunteer with the International Medical Corps (IMC), who arrived soon after the January 12, 2010, 7.1 Richter earthquake. While having volunteer doctors do some direct service, the IMC's major volunteer mission was to train Haitian physicians and nurses to do better ongoing clinical work themselves, both medical and psychiatric. The IMC follows the old adage: Give a person a fish and he eats for a day; teach a person to fish and he eats for a lifetime.

Of course, every volunteer physician or nurse, every psychiatrist, brings his or her own 'baggage', own discipline and experience, own strengths and vulnerabilities, resulting in a range of unique volunteer experiences. Yet there is a common thread to all of this, weaving a story worth telling for future volunteers to consider. By walking in another volunteer's 
moccasins doing Haiti psychiatric disaster work, you can better prepare yourself for what lies ahead as you embark on your own volunteer effort. Hopefully this will lessen your culture shock, improve your clinical skills, and deepen your satisfaction as you do this demanding work.

While surgeons and medical doctors have certain defenses allowing them to do their arduous trauma work, these same (necessary) self-protections make them variably more immune or less aware of certain other things. On the other hand, psychiatrists, to do their intimate emotional work with trauma victims, have to let down their own guard and become more open to their patients' and their own inner experience, potentially putting them at greater risk in disaster situations. But this openness also gives psychiatrists unique perspectives. These insights can be useful in disaster work in general. Embedded in the ongoing narrative of this chapter are most of the principles and practices of disaster psychiatry. The specific approaches presented represent one particular practitioner's way of doing things, guided by IMC principles; but general principles and application techniques emerge around a wide range of gripping cases.

At heart, this is the remarkable story of a seasoned older psychiatrist who once lived in Haiti as a young Yale undergraduate anthropologist, returning now to spend a grueling month on the front lines of the Haitian relief effort-an experience confronting him with unexpected medical and personal challenges, harbored in long-forgotten buried corners of his own mind.

By offering a candid first-hand description of his time in Haiti-making us feel we are there in the tent and the clinic with him-he provides a memorable basis for understanding and applying the principles of disaster psychiatry.

His journey begins in France.

\subsection{Tuesday, february 16, 2010: Foie gras and fate}

I was sitting there quite alone at a crowded table when the call came. We were in the Dordogne enjoying foie gras and truffles. I was trying to forget the earthquake that had ravaged my beloved Haiti. I didn't want to ruin the Les Liaisons Delicieuses trip my wife had worked on so hard to create. But some 50 years ago, as a Yale undergraduate anthropologist I had lived in Haiti with a voodoo priest and his family just outside Leogane, now the epicenter of the quake. I had kept in touch with my friends there, recently receiving first hand reports of massive death and destruction. Sad and guilty, I feared I would never be asked to join the medical relief effort, wondering if it was because I was now 70.

My French cell phone vibrated in my pocket, jolting me back to reality. Embarrassed, I turned and cupped my hand over the phone. "Who is it?"

“Drs. Lynne Jones and Peter Hughes from Haiti with the International Medical Corp. Do you have Skype?"

"Yes, down in my room."

"Could we call you back in a few minutes? What's your Skype name?" 
Twenty minutes later I reappeared at the table, after an interview about my psychiatric background and perspectives on disaster psychiatry. They had actually quizzed me on how I would handle the case of a dazed incoherent Haitian woman found naked walking the streets of Port-au-Prince.

“Why are you looking so ashen, Kent?" my wife asked me. 'What just happened?"

“They want me to come to Haiti. They're starting up mental health teams near Leogane in their emergency mobile medical clinics."

"I thought that's just what you wanted?" Rod Drake, my closest Washington psychiatric friend, threw in.

"I never thought it would actually happen." Then I recalled my surgeon brother-in-law, Mike Ribaudo's warning, "Be careful what you wish for." Well here it was, the die was caste. I was about to face the biggest challenge of my life. Apparently, the Washington Psychiatric Society and World Psychiatric Association had sent my resume on to the International Medical Corp.

There was a hitch, though. After being processed to go, I received an email from the IMC deployment officer saying I had been put on extended hold because of overstaffing. Hurt and miffed, I emailed back an impassioned rejoinder, "Take me in the next few days or I'll go elsewhere!" I didn't want to miss my chance. I also copied Lynne Jones.

Lynne fired back immediately, “Hold on Kent, this isn't coming from me. Let me see what I can do." Within one hour I was off hold and back on track--my first taste of what a brilliant bulldog Lynne could be. She's a British Child Psychiatrist, and a great clinician, teacher, and administrator. I soon learned nobody messes with her. Thank god somebody like her is down there in Haiti, I thought.

\subsection{Thursday, march 4, 2010: Paris to Port-au-Prince: Time warp}

During my check-in for departure from Paris, Air France charged me $\$ 300$ overweight for my medical supplies and equipment. I even reminded them Haiti was their former colony to no avail. Aboard the plane, seated on my left was a French sapeur pompier, with his large fire and rescue team behind him, ready to do rescue and water purification. On my right was one of the top people in WHO who told me that within the first two weeks there he had to coordinate 240 humanitarian groups, medical and otherwise. He was returning after a break to deal with a much larger number, though some were pulling out with the most acute phase ending.

Just before I left, my sister-in-law Polly, a nurse, talked to her colleague on the hospital ship Comfort, moored off the shore of Haiti, who told her, "We've been swamped with the worst cases I've ever seen, many dying, but many saved. I had one little girl with a horribly infected face, worms and maggots crawling out of her festering wounds. Polly, we've never seen ANYTHING like this. No war zone compares. But, you know, I've been moved to tears by the strength and spirit of the Haitians I've seen." Just as I was packing up, Patti told me about the conversation with Polly, then looked me straight in the eye, "Kent, do you really know what 
you're getting yourself into?" My anxiety shot sky high, "Please, that's enough. I have too much to think about already.

For me, at least consciously, I was more worried about my so-so French, my rusty Creole, and my ability to help psychiatrically in the midst of such devastating physical tragedy. Finally, I said, "Going down to Haiti feels like the biggest final exam I've ever taken. I thought I was completely finished with things like this." I have been plagued by performance anxiety all my life, and was glad to be done with it. "I'm not worried about how you'll do," Patti said. "I'm worried about your health and survival." "What about your pulmonary embolus three years ago. And the Coumadin you're still on?" "It'll be okay." I said, "My health's pretty good now. Stop being so anxious." "Me? Look at your hands, Kent." We both stared down at them. They were trembling. "I've always had that hereditary tremor, nothing new. You know that's why I didn't go into surgery." "Come on. You're vibrating like a tuning fork." "Okay, so I'm a little anxious, but I'm going. I have to. You know why. And I need your support." "Just be very very careful," she murmured.

As the plane for Haiti took off, my cabin conversation slowly gave way to personal reflections. I slipped on earphones, and leaned back. A subtle sadness filled me. Intimations of the loss of the Haiti I knew 50 years ago came into my mind. I had experienced Haiti back then in the youthful blush of naive enthusiasm and brash denial, allowing me to tour carefree all over the country. Now TV images of collapsed buildings and survivors being hauled from rubble floated through my mind. I had glimpses of what I would be dealing with once I arrived. And I would be seeing it from my sobered vantage point now later in life. Even so, I felt a shudder ripple through me. Something more was troubling me. Something deeper. Just then, "Haiti Cherie" came over my earphones, taking me back to glittering evenings dancing at the posh Petionville country club. I was able to push more depressing thoughts away with these pleasant memories.

My first summer in Haiti had been such a high, the stuff of dreams. I was in love and loved what I was doing. I chronicled everything, capturing it all in love letters to my girlfriend Linda. I had met Maya Deren in Greenwich Village as a Yale junior. She had lived with a Voodoo priest, Isnard, during her Guggenheim to study Haitian Vodun dance, and authored the fascinating book The Divine Horseman: The Living Gods of Haiti. My hope was to study Voodoo spirit possession and try to understand its behavioral content and psychodynamics. The project took on such major proportions I applied for Yale's Scholar of the House Program, freeing me from all class work save presenting my research work monthly, and writing my Scholar of the House thesis. When they accepted me I was ecstatic. I was still doing my premed courses on the side. Memories kept filling my mind.

Someone tapped my shoulder snapping me out of my reverie. "Would you like a snack?" the stewardess asked? "No, I'm having a delicious time as it is," I said, slipping immediately back into my daydreams. Then I fell asleep. In my dream from the corner of my eye I thought I saw something black and hairy crawling onto my left shoulder. I screamed and sat bolt upright, wrenching myself away from it. I scared the hell out of the French fireman next to me. "Hey, buddy, you all right?" "Sorry," I said. "Must have been a nightmare or something." I had also bumped the WHO guy next to me and he was eying me suspiciously. "I'll be okay. Just a bad 
memory." I settled back into my seat, not at all sure I wanted to close my eyes again. Haiti was rapidly coming closer and my second summer there had been a nightmare, including two encounters with the tarantulas living in my room. Momentarily I put my psychiatric hat back on, realizing I was having a return of my post-traumatic stress disorder. As our jet approached Hispaniola, I found myself wishing we were in that old slow prop-driven plane of yore. I needed time. I had been enthusiastic about going, despite my anxiety. But the reality was fast approaching. Was I equal to it?

When the devastating 7.1 magnitude earthquake hit Haiti in January, because I had been an undergraduate anthropologist in Haiti 50 years earlier, my deep love for her people moved me to volunteer. Back then, I was an undergraduate living with a voodoo priest and his family outside of Leogane (now the epicenter of the quake), doing research on voodoo spirit possession, contributing to the theory of multiple personality. Now I was a 70-year-old retired psychoanalyst and child psychiatrist, facing a month's tour of duty with the International Medical Corps. Soon after I arrived they sent me to Petit Goave just beyond Leogane, to form a mental health team serving the five IMC mobile medical clinics (including one boat clinic for a fishermen's village). 70 to $80 \%$ of area houses were damaged or destroyed, killing large numbers of men, women and children. Surrounded by death, destruction and dislocation, the surviving people constructed makeshift tent cities everywhere, with donated tents finally arriving later. Survivors from the Capitol poured steadily into this outlying area, aid lagging far behind.

\section{Training mission}

Soon after I arrived, I found out what the International Medical Corp had in mind for me. Our IMC mission, while providing urgent psychiatric care, was aimed primarily at training clinic Haitian family doctors and nurses to do independent sustainable psychiatric assessment and treatment. IMC emphasizes water, food, shelter, community, and security as essential to recovering mental health. Our psychosocial clinics stressed emergency psychiatric intervention techniques designed to help people deal with mass trauma, dislocation, loss, grief, anxiety and depression, as well as seizures and acute and chronic psychotic illness. We also taught a basic psychiatric pharmacy. Like military psychiatry, we focused on interrupting stress, anxiety, phobic and depression-based symptoms interfering with normal grieving and selfrighting after mass trauma - linked with strengthening of family, friends and community

My personal mission was to create a mental health team that traveled weekly to each of five medical clinics, providing clinical teaching for the clinic doctors while we gave direct patient care. I also had to give two Saturday trauma psychiatry lectures and workshops to the Haitian clinic doctors and nurses - a daunting task since they were on the front line and I hadn't had any experience with them or their patients yet. Right after arriving, I gave my first workshop and lecture. After a sleepless night of frantic preparation, I took a deep breath and waded in. 


\section{Trauma psychiatry seminars}

In our Saturday Seminar we taught 12 Haitian doctors and 19 nurses from our 5 clinics, plus residents from Notre Dame hospital. I did a group exercise teaching them relaxation and imagery techniques to interrupt cycles of anxiety and repetitive thoughts, and then while in the relaxed state, had them visualize where they were when the earthquake struck, helping them recapture and work on their own inner experience, to increase empathy for their patients. I stressed cost-effective front line stress reduction nursing group sessions for people they identify--just a session or two, using techniques I was modeling with them

In my lecture, I stressed the importance of their health care presence at the clinics which were strategically placed in or near the tent camps and the destroyed villages, reinforcing the impact of their caring presence and caring activities, their laying on of hands, their quick but careful exams, including their mental health first aid and triage. As front line workers, their work and reassurance gave hope and momentum to recovery for this vast impacted impoverished, yet strong resilient group of Haitian people, helping them move along in their expectable stages of recovery from a mass disaster. I emphasized that they should think of how to normalize their patients' 'abnormal' experiences, maybe based on their own seminar guided-imagery experience I had provided for them earlier in the day. This might help correct their own and their patients' dire and fearful self-diagnoses, stirred up by their new 'symptoms', their expectable range of new weird thoughts and feelings. They needed to be careful not to overly 'pathologize' what their patients presented by becoming familiar with their own experience, by coming to know the normal stages of mass disaster recovery. This would help themselves and their patients avoid getting stuck and becoming chronically symptomatic.

I emphasized the individual and group importance of their presence at their Clinics, that they were, just by their presence, and their laying on of hands and manner of caring, a transference object of great importance for the tent camp and village they were in, becoming a healing beacon in a troubled mental sea. Although I knew they felt guilty about the long lines every day, and their brief problem-focused encounter with each patient, I said that their Haitian patients were used to waiting for care, care like they had never had before, and that even waiting in the clinic near their doctors was curative as part of the placebo effect. Just knowing the Clinic was there mentally, and spreading the word to the camp or village, was good for people. I repeatedly emphasized that they were on stage for their patients, as they delivered care in these open tents with every one watching, and that they should never underestimate the importance of using themselves as a powerful part of the healing. Patients who sit and wait are in a healing presence that sets the mental stage and also cures in its own right.

IMC also stressed how much shelter, food, water, security and reunification or 'retribalization' means (including connecting people with religious and secular groups if their own families are shattered or dead) in providing the substance and holding context for their recovery from mass disaster. Several nurses and doctors shared their own family experiences, and then, feeling safer and more encouraged, their patient experiences. Then I looked directly at them and asked them how they themselves were doing, asking for a show of hands about how many 
had lost family members, how many had their houses destroyed, how many were living in tents outside their houses, and how many in tents in the camps.

Though many were more fortunate than others, all were traumatized, and about a third had been deeply affected one way or another, many with significant losses, several now living in the camps. When the subject of tents came up, Inoticed two nurses looking down and huddling privately. I finally asked if they could share what was going on. With some embarrassment but plucky honesty, one nurse confessed she didn't even have a tent yet and was living outside with family members in one of the camps, grateful the rains hadn't come, and proud she made it to the clinic every day to work, somehow looking clean and kempt. It seems tents are now in short supply in Haiti and there is still great need.

I had actually volunteered to live in a tent when inside beds in our IMC residence were in short supply, but now I suddenly felt guilty. One nurse knew about it and spread the word in the audience while I was talking about all this. I heard muffled laughter and finally asked what was going on. The nurse finally confessed, adding, 'So you're in the tent city just like us!' I smiled and shook my head. Everyone laughed.

I also stressed that my team role and mission, in addition to helping provide direct urgently needed psychiatric care, was aimed at training Haitian family doctors and nurses to upgrade their mental health skills. We all agreed they wanted to become more adept and independent in this area, wanting to improve their own psychiatric assessment and treatment work in their medical clinics.

During the lunch break, as everyone else made a mad dash to be first in the buffet line, one young doctor came up to me and said he was unsure about the purpose and usefulness of the imagery recall exercise. When I explained it again, his eyes rimmed with tears. He told me about pulling children, some dead, some gravely injured, from under crumbled concrete slabs in the house next to his after he and his kids managed to get out safely--just before his own house finally collapsed completely. We talked at length, he was grateful, and I thanked him for having the courage to talk with me.

I knew I'd be working with him soon in one of my weekly clinic rotations, and was deeply moved by his experience, and by the group at the conference. All this certainly broke the ice for me, and I hope for them. I felt poised, ready to go out to meet them on the front line, working along side them, treating their patients with them. At that point, though, I was all enthusiastic readiness and no real experience. Unless you count working in a Washington, DC, inner city emergency room.

How would I do? I had a strange thought. I should summon up voodoo god Maitress Erzulie Gran Freda, and say, "Please come up from the abyss. Be my divine guide. Help me to find the healing words I need". Where did this come from? Then I recalled my last day in Haiti 50 years ago. The voodoo priest I was living with had taken me aside, into the inner sanctum of his temple. He went into a trance, and his Maitress Erzulie possessed him. In her characteristic deep gravely voice she said, "You have already sewed fingers back together, and treated our TB and dysentery, so for us you are already a doctor. But some day after you finish your medical 
school, you will once again be called upon to come back to Haiti to serve us again in our hour of greatest need. Her words comforted me even as a chill ran down my spine.

Now that day had come.

\section{Clinical training and treatment}

\subsection{Petit Guinée clinic}

Let me tell you about my initial days in one of IMC's clinics, the Petit Guinée Clinic, to give you a taste of my experience.

As we bounced along in the van, one doctor quoted a most recent CNN commentary, which said the rubble from the Haiti earthquake would fill the entire Washington Mall to the height of the Washington Monument. My heart caught in my throat as a realized with fresh impact what they were seeing. As we drove along, we saw a house totally destroyed, with a slanting slab of roof, now taken over by goats standing at the peak. At least they wouldn't be eaten at night, unlike the 'free-range' chickens with nowhere to hide. I now had more sympathy for the roosters and realized why they were crowing at all hours. Packs of hungry dogs roamed the night, seeking whatever they could scavenge, given the scarcity of food and leftovers.

On the way to Petit Guinée we drove through the poorest section of Petit Goave, a beautiful seaside location, but also one of the hardest hit. As we arrive, the Petit Guinée patients are registering as Drs. Affricot and Louis confer with nurses.

I was privileged to see how the staff set up the clinic. Patients were already sitting on fractured cinder blocks for stools, squatting in classic 'Haitian style' all around the periphery, perhaps 75 people strong. At Petit Guinée Clinic, some mothers were breast-feeding, other mothers and fathers holding sleeping children, all eager but respectfully waiting for a turn--all huddled under a huge, slightly twisted corrugated roof with open sides. Tables were set up, and blankets suspended and tied into makeshift walls, giving a semblance of rooms and privacy. Chairs were at a premium, as were tables. I had worried about how things would be set up, so my nightmare wasn't in vain. We came well prepared, all very useful as the clinic began to roll. I was given a corner up on a cement dais, a remnant of some sort of stage with a shiny pole in the center and an old bandstand. At that point I was oblivious to the former nightclub we were working in.

Dr. Affricot was chief of the clinic that day. So there I was on stage for my first teaching clinic. Without a drum roll we saw our first patient.

Pierre, a shy, taciturn eleven-year-old, was sleepless, constantly hearing the cries of a baby, and the voices of dead neighbors. He had been holding a neighbor's baby when his house collapsed on him. His mother could only see his head when she tried to rescue him. He tried to protect the baby in his arms, but it was gasping when they got him out. The baby died on the way to the hospital, crushed in his arms. He felt horrendously guilty, not helped by the baby's angry grieving parents, whose house had also collapsed. His mother added they 
weren't really talking about him personally, but he felt guilty, even for surviving. He had had a friend die 3 years earlier and heard his voice for a long time, thinking at times he even saw him in groups of children, until taking a second careful look.

I worked with the doctor to do the interview, using the interpreter to get the story details and give feedback, providing guidance, at times even speaking in my rusty Creole to the boy and his mother. I said he had made it through the mourning of his previous friend. He had more experience with this kind of thing than most kids. We told him he had more complicated grief work to do this time, but by past experience had what it took to work his way through this one too. We said we felt he would do fine. We told him and his mother he was doing too much emotional work in his sleep at night, giving him bad dreams and sleepless dreamy voices during the day. I explained they needed to bring this into the daylight when he could do more effective emotional work.

The mother was advised to have a little session with him each evening to gather all his worries into her mind and arms, helping him clean and clear his mind, reassuring him she would work on them for him so he could sleep-kind of like what you do with Guatemalan worry dolls. She should also tell him he had done all he could for the baby. Nobody could have protected him more, not even his parents. Because he was a shy boy with a strong conscience, making him very self-critical, she needed to tell him to ease up on himself. We gave no meds, but rather a follow-up, saying we felt they would be a good team during their healthy grief homework. They left encouraged and armed with active self-help they could carry with them

The next woman had severe palpitations. She was on the way home when the earthquake hit, seeing friends in front of their destroyed houses wailing for dead or missing children. She rushed to see how her 5 children had done, finding 4 alive in front of their collapsed home, 'Grace a Dieu'. But her $5^{\text {th }}$ had not made it home from the school, which had partially collapsed. She wanted to rush out to find her, but her children reassured her she would come home. And she finally did, with stories of other kids being hurt or trapped. It was 3 days later, a delayed reaction, that her short agonizing vigil waiting for her daughter triggered severe palpitations.

She had pre-existing high blood pressure, was on a medication, and worried her heart was giving out, with bursts of rapid beating (palpitations) making her feel she was dying. She let us know she was helping many of her grieving friends, and felt her heart problem was physical. But she had never had this before, except slightly walking up steep hills.

It became clear, after taking her blood pressure and taking her pulse rate, and listening to her heart, that she was physically okay, though we agreed she should see her doctor to get checked out, maybe even have an electrocardiogram. But I told her we knew what was going on, and that she had the strength and intelligence to work this out, letting time and simple techniques restore her trust in her body and in life. I explained the endocrine fear response and her tendency to make scary self-diagnoses escalating her panic. We noted her previous fast walking would make anyone's heart beat faster, and that the new bursts of heartbeats were different, a normal fear response that had gotten a little stuck. To deal with that she needed a couple of techniques to counter thoughts or noises, or after shocks when they triggered them. 
We taught her to blow into a sack and the Valsalva maneuver, like when you bear down to grunt at toilet, or during childbirth.

The Valsalva causes a neurological reflex (vaso-vagal) that slows the heart. You may have read about this in diving mammals. We told her to use it to interrupt the beginning palpitations. This both works and is a cognitive distraction. Just knowing you could take control helps a lot. We also showed her the paper bag sealed around the mouth re-breathing technique used for hyperventilators, but also for palpitations. The 'sack' re-breathing technique decreases $\mathrm{O} 2$ and increases $\mathrm{CO} 2$, and distracts - decreasing her overbreathing and tingling and dizziness caused by excessive breathing and increased $\mathrm{O} 2$ levels. We also urged her to be a smart scientist, noting down obsessively each time she had such an attack, so she could outfox the triggers, and disconnect them with an 'I told you so", just as she could help her friend do. She needed to be a kind doctor, and not scare herself. She got the hang of it, and understood the psychology and physiology of it. She was a schoolteacher so I suggested she could help teach this to scared symptomatic friends, as she herself got good at it. By becoming active and masterful and a 'trauma recovery teacher', she could help everyone.

Another patient was glassy-eyed and depressed, showing us a certificate of scholastic accomplishment earned by her 21 year old son. His handsome picture smiled up at us from the certificate. Between sobs she told how he was teaching in Gressier, away from home for a while, and was crushed in his little room by the earthquake near his school. She was almost inconsolable, in deep prolonged, but not 'arrested' mourning, yet was bordering on depression. We listened with near reverent attention, checked on her friendship and religious network, and noted she had high blood pressure. She also had serious insomnia. I suggested they add Atenolol, both a relaxing sleep promoting and anti-hypertensive medication, hoping to help her through this sad, sad passing. She had other children to live for, but we would follow her up closely next week just to make sure. We felt we needed to keep her alive for all of our sakes, and asked an accompanying friend to keep checking in or her and to bring her back for her next appointment.

We saw other patients, and as time went on I relied on the Haitian doctor more, since we were hoping to give our clinic doctors increased front line competence, a good sense of basic psychotropic meds, and diagnostic acumen for triage--and referral, if absolutely necessary. But where could we refer? The psychiatric hospitals were mostly destroyed or seriously overcrowded and understaffed. There wasn't much psychiatric care to go around, and most people, even if deeply affected, were, with simple help, resilient and self-righting - if they had their basic needs met, that is, shelter, water, food, and security, plus some social connectedness. We had to do what we could, enlist friends and community, and just tolerate the uncertainty as best we could.

We had one other woman in the Clinic today who lost one child, an aunt, and her house. Her business establishment also collapsed and then was looted, and, her van was trapped under a concrete wall. So she and her family were without even a tent and no means of livelihood, after enjoying a comfortable, productive middle class lifestyle. She was depressed, and, I sensed, quite angry underneath. Because of this and a sense of pride, she was unable to reconnect with, and in fact avoiding, her Pentecostal Church. She seemed close to needing 
antidepressant medication, but we gave her a light sleep med at this stage. She and her IMC Haitian doctor preferred it this way. He pointed out to me one had to be on costly antidepressants a long time, and we sensed she might come around the corner if we waited. We planned to see her again next week, just to make sure. Taking the mental pulse and providing close follow-up were the key. We didn't want her remaining children to suffer a maternal suicide because we were too conservative and cost-conscious, given everything else. But for her this proved a wise choice. Her doctor had really connected with her, they were on the same wavelength, and later I would see her coming back to see him.

\subsection{Mirogane clinic}

Now I'll tell you about another day, at the Mirogane Clinic. Mirogoane is an hour by van from my base in Petit Goave, over a road full of ruts, the roadside lined at times by beautiful coconut and banana trees and sugar cane fields, with a gorgeous backdrop of crinkled denuded mountains, a deceptive sprinkling of green scrub growth in a few places. The trees are scarce, mostly cut down for cooking charcoal due to overpopulation pressure. Looking ahead from the van I see throngs of people, collapsed buildings, goats attacking burning refuse for fruit peels. Gaily panted trucks and cycles hurtle toward us, with tent cities rushing by on either side. The road is periodically scared by those zigzag crevasses, and deep cleavage drop offs, stunning reminders of earthquake forces scarring our poor Haiti, each mercifully requiring us to stop our headlong rush from time to time-the new Haitian equivalent of speed bumps. Speaking of these, because tent cities are all along these mostly mud roads, and the dust horrendous, people in these roadside cities create big, makeshift mud speed bumps. Only the animated conversation with some volunteer Hopkins Docs, assigned for the day and Nurse made me forget the life, and death, teaming around us.

Pulling up to Mirogoane Clinic, I haul my red backpack up the steps to a clinic bursting at the seams with Haitians, all camping out patiently in anticipation. I had been told there would be plenty of chairs for my mental health clinic in Mirogane, only to find they were scarce. They tried to put me out among the people in plain air, but I scouted around and found a cramped back room, moving soiled instruments and half-empty bottles of medicine and antiseptic out of the way. Finally, I scrounged up three bent rusted chairs and a bench. I was in heaven, and in business. Except no ceiling. The wall went up only 9 feet to a high airspace transmitting the hubbub from the next room. Good for ventilation but not privacy. And there was no door.

After getting oriented with my Haitian doctor, Dr. George, our first patient walked in, referred by one of the Hopkins gals. Suffering from earthquake losses, and quake shock anxiety deepened by aftershocks, we prescribed her some Diazepam and anxiety reducing exercises which we demonstrated (progressive relaxation and deep breathing techniques). We added the 3-breath-technique, where you take a deep breath, hold, then take it deeper, hold, and then as full as you can and hold. You do this three times, concentrating on your breathing. Doing this is incompatible with remaining anxious. We also prescribed homework telling her to share her story with family and friends to reconnect her with her own experience narrative.

In the midst of this, a toothless wizened old man, drunk as a coot, came rolling into the room giving us all high 5's. He was to be our next patient, but inebriated and high, he had jumped 
the gun--his poor impulse control written large in the breeze, along with his rancid alcoholic breath. We saw him next. He was infectiously delightful, all a sad deception. As he raved on, a tear dropped from one eye during a fleeting mention of losing a family member, covered immediately by gay word torrents. He told us he had been drunk most of the time for 8 years, and that it was his sister's fault. She had been a raging alcoholic before him, until she saw a Voodoo priest who, for a sizeable fee, removed the "devil drink" from her, unfortunately putting him in our patient. I helped Dr. George accept this story with a straight face and explore the personal causes and all the awful sequelae of such chronic drinking (black outs, the DT's [Delirium Tremens, famed for its kaleidoscopic 'pink elephant' hallucinations] and WernickeKorsakoff syndrome [with its loss of memory and sincere confabulation], etc). Miraculously, he had been spared by the earthquake and lived to tell his story. I had the doctor do a careful mental status to see if our patient, besides intoxication, had the hint of other brain damage. He seemed pretty clean, to our surprise. We were naively hopeful. But hope is important for everyone in this kind of situation, including - or especially - for us treating doctors.

Then I asked if Dr. George had seen the patient's brief moment of tearing up. He recalled it, so I asked him to explore what lay behind this fleeting hint. A lot of underlying isolation and sadness emerged, which the patient usually camouflaged by his "hail fellow well met" veneer. Picking up on his sister's exorcism, I said to him I knew about Voodoo, and had thought of taking training myself for the Ason (the priesthood). With a knowing smile, I said we would be willing to receive his 'drink devil' if he wished to give it up to us. But, we said, we could not give him a proper examination for diagnosis and a path toward cure unless he were sober. Looking him in the eye, Dr. George asked him if he could try being sober for the upcoming week, to get his body and mind ready for our next visit? The patient's eyes grew wide, then narrowed, and he accepted the challenge. This was based on our sympathizing with his underlying loneliness, which had touched him deeply. Without challenging his beliefs, we told him we felt he was taking the wrong medication, his self-prescribed alcohol. He agreed to come back the next week. Chronic alcoholics are tough, especially in this environment, and yet this guy had pluck, and the obvious available mental hook revealed by his tears. But we would have to wait and see

Then this lovely healthy-looking but somber young woman, 21 year old walked in, complaining of insomnia, palpitations, visions and voices, but of a very particular kind. The voices and faces were fellow medical students and young nurses who had been trapped together with her in the basement as their building collapsed on top of them, there in Port-au-Prince. Trapped in pitch-blackness, pinned under rubble, she could hear the voices, the screams and cries, of those injured and dying all around her. Over four grueling days she heard these voices, voices of her friends, holding their faces in mind to keep herself going, only to hear those voices becoming fainter and weaker, and finally dying out, leaving her alone with only one friend's voice, somewhere way up above her. This faithful friend knew she was down there somewhere below her, and told the rescuers, when she heard them above her on the third day, saying she was alive down there somewhere below her, guiding them in both their directions. Then her voice, too, became weaker, and died out somewhere above her, leaving our patient utterly alone. 
As rescuers got closer to our patient, at first her own voice was too weak to call out on her own behalf, though she could hear them calling her name. Finally she found the strength and called just once, loud enough to be heard. But the rescuers found that the pieces of concrete over her were too big to be moved. They told her they wouldn't give up, but they feared they wouldn't be able to do anything soon enough, telling her she should hold on as long as she could, and they would do their best. She lost hope though, hearing rescuer voices growing faint above her, as she hung in darkness, her sense of day or night completely lost. Her throat was parched, and her loneliness deafening, but she didn't give up. She was the last of all her pre-med friends to survive. Then, finally someone got to her feet. We found out, at that point in her story, that she had been suspended upside down the whole time. As she talked with us, encouraged by us to open up her darkest hours, her voice grew stronger, calmer, and more certain. I finally blurted out I was so proud to have someone like her becoming a member of our profession.

She broke out in a radiant smile, and told us she was hoping to go back to medical school when classes started. She would be finding out the next day when that would be. As she said this, her voice quavered and got softer. She already knew two thirds of her class of 45 had died, and confessed she was petrified about going back. She was having palpitations and hyperventilation, with near panic attacks whenever she thought about getting near the collapsed medical school building again. She dreaded finding out if even more had died, and wondered about the teachers. Dr. George and I gave her some diazepam to take the edge off her anxiety, and help with her insomnia, and gave her three desensitization and behavioral techniques which would give her ways to systematically move toward mastering her feelings of fear, her foreboding thoughts of impending disaster, and her phobic avoidance of her school and the future.

As we went over these techniques we found out she had been a student leader, and suggested she might be a good teacher and leader for student groups with whom she could share her experience and techniques for their shared anxieties, helping classmates to resolve their symptoms. Facing her own understandable feelings and reactions, using all her robust strength, might allow her to return to her support community and show them how to work together, to resolve their shared fears and losses and accomplish mass mourning. By the end of the session we had a sense she would be able to make it, and help shed light on the darkness they all faced. We asked her to come back with a journal of her homework accomplishments to an appointment at our next clinic, a week hence, if she didn't remain in Port-au-Prince. We told her we all felt she, especially, would be able to make it. We clarified issues around survivor guilt, emphasizing that she was living for herself, and that her self-exploration and healing would allow her to be a fine compassionate doctor sometime quite soon.

As I write this, tears are streaming down my face. This young woman, in particular, takes my breath away and makes coming down here worthwhile. But doing this kind of work is often like doing surgery without benefit of anesthesia, and yet painstakingly important. Many of my young Haitian doctors felt it was mean to have patients remember and feel what had happened - until they saw how it unlocked and freed people to face and re-embrace their lives and their hopes for the future. I didn't have time to decompress while working with our Haitian patients, and didn't discover how much they were affecting me until I try and write about it. 
I admire the strength of many of the people I see and yet don't want to be too idealistic or naive. Or too optimistic. We do what we can, and hope for the best.

The next patient was a 22-year-old girl, with trouble speaking because of a tight, tremulous aching throat. "Feels like a lump in there," she said. She also had trouble keeping her eyes open when this was bothering her, and dizziness and hyperventilation. All of this had happened, on and off, in the past--around failing to get in medical and then social work school. The symptoms reappeared with the earthquake, coming in waves. It was then that she mentioned her brother had died in the quake, someone she was very close to. The moment she heard of his death, she couldn't open her eyes for hours. Her other brother in Cap Haitian was calling and crying openly, but she couldn't cry at all. My translator Tessier, a teacher, tapped me on the shoulder, "Dr. Kent, I knew her brother, a student and a friend. He was a great guy. I feel so sad to hear my friend died." He had a rim of tears. "What a loss."

I said, "Tessier, tell her what you just told me." When he did, she began to cry, but her throat tightened up, her voice became strangled, and her eyes started to scrunch shut. And the crying stopped suddenly, as if caught in her throat. I said to the Haitian doctor, "See that, she has Globus Hystericus, or anxiety-based laryngospasm. Some people call it the "Stifled Cry Syndrome". She is using hysterical conversion to protect herself from overwhelming loss and sadness, a kind of psychophysiologic spillover into her body from her intolerable broken heart. She needs to close it all out, not feel it and not see it with those scrunched up eyes. When her normal waves of sadness hit her, coming up unexpectedly from her body, she cuts it off by this defense resulting in her symptoms. But she's on the road to recovery if we can help her, or get her family to help her, face her brother's loss and tolerate her mourning."

"Should I tell her all this?" said the Haitian doctor. "By all means, but also include her aunt here, and additional calls with her brother, so they can work together on this. Make it definite homework. We can give her the Sac Rebreathing Technique for her hyperventilation, as well as Relaxation, and Imagery approaches, but her best bet is family help through shared family mourning. Have her come back to see you briefly for several follow-ups. You can really help her a lot with very little."

The next young man, a 27 year old, was a follow-up. For the second time in his life, he had lost close friends, though unscathed himself. But he had ended up not being able to hear very well. Voices seemed far and faint. After carefully surveying his history and hearing situation, we felt he was having hysterical negative auditory hallucinations, basically losing hearing ability because his school had collapsed and, on a deep automatic level, he needed to keep from hearing all the horrible things he had heard. The shouts and screams of those dying or suffering around him, as well as his own petrified unvoiced thoughts. So he virtually gave up hearing all together. He had heard all the voices of fellow students below, the injured screaming in agony - voices he kept hearing in his dreams and waking mind's ear. He was plagued by nightmares, which constantly awakened him. He desperately needed to get rid of all this so he could stand his own mind and not be held hostage, or driven crazy. He wanted to be free to pursue his life. But the cost of his hysterical protection was severe, not being able to hear other things in order not to hear these anguished cries. 
In his follow-up visits with Dr. George, this being the third, with support and some anti-anxiety medication, he was already beginning to hear better, and as memories and feelings came back, he was becoming flooded with painful but laudable (valuable rejuvenating) grief. In coaching Dr. George, and trying my hand at a formulation and interpretation in my 'French-Creole', I was able to give him the conceptual tools and his patient the self-empathic support to understand his tortured mental journey. Dr. George gave him hope and courage that the road ahead was possible and the end point 'in-sight'. In was particularly gratifying to work with Dr. George. He was quite sensitive, and also the doctor who had come up to me during my first seminar sharing his own losses. He was open to his patients, their profound grief--tolerating and sharing through his inner empathic resonance.

Dr. George and I discussed the fact that this bright sensitive, fairly timid and inhibited patient had been able successfully to get through similar symptoms with his pre-earthquake loss, which gave us hope, and a predictive model for recovery, and a basis for a hopeful prognosis, though we emphasized he was carrying and bearing a lot more this time. We also discussed the burdens and pitfalls of survivor guilt, and the needed self-maintenance around it. I encouraged his continuing work with Dr. George, discussing his self-protections. I felt his more primitive early defenses were giving way to healthier and healthier ones, now resulting in the painful but constructive waves of grief, and associated guilt, as he dealt with his losses. We urged him not to be ashamed, but to write in his journal and to begin to have the courage to share has experiences with close friends and family. We invited him to come back in a week to help us appreciate all the hard good work he was doing. He left confirmed in his continuing progress. I was proud of his Haitian doctor's work with him, which I shared with him after his patient left.

Our last patient was a cute little girl, 5 years old, with severe developmental delay from birth, who had seizures and had lost her medication when her house caved in, and her doctor had been injured and was unavailable. So she needed to get her two seizure meds from us. We breathed a sigh of relief at such a routine request, which we filled with pleasure. We determined in the process that her medications were not controlling her seizures very well so arranged to adjust them and have her come back until we got them right.

My gifted interpreter, Tessier, a schoolteacher out of work because his school had been damaged (in general the schools were still closed), turned out to know a lot about these patients and their families. After the Clinic he confessed he felt dizzy and drained, and a little sick to his stomach. We both commiserated about all we had heard, agreeing it was a lot to swallow, especially with open hearts and minds. We both needed some R \& R. And yet he felt he was privileged, and learning a lot. He also pointed out that the head nurse, who had been at my opening seminar, made it a point to come and sit in on our work. I had a hunch this would pay dividends for her and for the clinic, benefiting future patients. We all looked forward to meeting again next week. I stuck my head in and gave the Hopkins doctor feedback on the patient she had referred to us.

My shirt was drenched by this point. My best self-care, though, was the fact that I had invested in a blow-up camp pillow, which at first I was embarrassed to take out, until my seat couldn't take the rock hard chairs any more. So I would blow it up, soon making it a ritual. Tessier and 
the doctors, and the watching patients, especially the kids, loved to watch. And boy was it comfortable during those long grueling sessions, where I had to have the quickly spoken Creole translated to me, and then my words fed back in Creole to the doctor, though at the end of each case I tried speaking some in Creole to model how to give interpretations, at times drawing quizzical looks, at other times confirmation of my words. Often, though, Tessier had to re-translate my 'Creole' into Creole. I was happy to be rescued. We kidded each other that he would soon be getting his own psychiatric diploma. I bought a BIG coke from a vendor on the way out which I guzzled thirstily on the long ride home.

My day at the Mirogane Clinic was but one of many over my month in Haiti, each a step along the way of my great challenge, one that brought me great satisfaction, and continuing profound sadness, as we moved along dealing with the Haitian earthquake disaster.

I should mention that Tessier surprised me two weeks later, sharp observer that he was. "Dr. Kent, you remember that alcoholic guy? Well, he came by while you were talking to your last patient, caught my eye, and whispered I should tell you he was doing much better, though he feels sad at times. He didn't want to take up your time. Tessier told him, "Yes, maybe sadder but much wiser and healthier now---keep it up! I'll tell Dr. R for you. And come around to see us each week. Seeing a success like you really encourages the doctors in their work." The patient seemed very pleased with the idea he could help the doctors, and said he would. He asked me to thank Dr. George and you. "And his breath?" I asked. "Not even a whiff of alcohol. He was sober." We both smiled.

\section{Summary of cases seen}

To summarize, I have listed the cases we saw at the Guinée and Mirogane Clinics during just two days of training and treatment. Let me alert you that these cases represent a sample of just two out of twenty clinic sessions I carried out during my four weeks of rotations to five clinics each week. And there were different medical and health personnel at each clinic. While these cases were supposedly selected randomly based on which patient was next in line, I suspect that the nurses made some choices behind the scenes, knowing I was a mental health specialist. I should also mention that this was before the American Psychiatric Association put DSM V (Diagnostic and Statistical Manuel) into effect. For these reasons, these cases are not a random or full sample of what we saw at the clinic, and the diagnostic nomenclature is used in a somewhat flexible and creative fashion. Many of these cases did not fit neatly into the usual categories, and often more than one diagnosis was involved. Reactions to Acute Traumatic Stress take many forms, depending on the person, his or her pre-existing medical and psychiatric conditions, and the particular family and the micro-circumstances of the trauma they experienced.

Guinee Clinic Cases

1. 11 year old Boy, with Arrested Pathological Grief Reaction, who was holding baby who was crushed to death in his arms, hallucinating dead baby's cries and screams of dying neighbors. Previous death of friend caused him to hallucinate voices 3 years early. 
2. 41 year old Mother of 5, with acute Anxiety Reaction, with palpitations after daughter late getting home from school.

3. 46 year old Mother of 21 yo teacher son with Prolonged Acute Mourning when son was crushed at school, now bordering on depression. Serious insomnia, pre-existing high blood pressure.

4. 39 year old woman with Acute Depression who lost 1 child, an aunt, car crushed, business smashed, looted, severe insomnia, isolating herself, angry underneath. Given sleep meds, since anti-depressant costly.

Mirogane Clinic Cases

5. 35 year old woman with acute Anxiety Reaction due to multiple losses, continuing quake/ after-quake shock reactions.

6. 41 year old man, a Chronic Alcoholic, drunk now for 8 years, with underlying Acute Posttraumatic Stress Reaction. Tear drops from his eye over lost family, word torrents. 'Devil drink' removed from sister by Voodoo priest, put in him.

7. 21 year old female medical student. Acute Traumatic Stress Disorder, after being trapped upside down, rescued after two days after listening to fellow students dying all around her.

8. 22 year olf girl, with hysterical Psychophysiologic Reaction, whose brother died, who develops Globus Hystericus,' the stifled cry syndrome' when she begins to remember and mourn.

9. 27 year old Man, with an unusual Psychophiologic Reaction in the form of a severe hysterical negative auditory hallucinations, beginning after hearing screams of injured, dying students and teachers, plus nightmares, insomnia. This could be under a definition of Acute Post-tramatic Stress Disorder.

10. A 5 year old Developmentally delayed little girl, with seizures who lost her medication and discovered her doctor was injured. her seizures were not well controlled we adjusted and gave her seizure medications.

\section{Community anthropology, voodoo, and collaboration}

What is missing in this chapter so far, especially one written by a former anthropologist now working as a disaster psychiatrist? The answer is: a description of the Haitian social structure and how understanding it can be harnessed to heal a fractured, earthquake-torn country. Knowing just enough about social structure can facilitate the care and teaching of disaster psychiatry in any country.

Putting the rare Haitian 'Elite' aside, Haiti has a small urban middle class, often recently evolved from and still connected with their country peasant roots. This middle class group is 
urban, enterprising, and usually Catholic or Protestant. In Haiti, at least $85 \%$ of the population practice Vodun or Voodoo. Out of experience, necessity, and wisdom, the Catholic church is quite flexible, and accommodates Vodun. As a wise peasant said to me, with some exaggeration, most peasants practice Vodun, and 100\% are Catholic. Among the small group that are Protestant, the Episcopals tolerate Vodun, while the Pentecostals are fundamentally opposed to it, feeling it is incarnate Devil worship.

Why 'incarnate'? Because virtually all who practice Vodun are possessed during ceremonies by Voodoo deities, and in that state give divine guidance and commands to the peasants, and even to the Vodun priest. After the possession state is over, the peasant has complete amnesia for what said or did. My Yale thesis is about Voodoo, and in particular, its religious form of ritualized multiple personality. While this may seem alien to most of us, Vodun is a rich, wise, and constructively prophetic religion from African roots. The Vodun priests are usually mature, influential leaders of the peasant community. The social structure, and often the placement of their Kay or small houses, center around the Houmfor, or Vodun temple. Vodun is a 'syncretic' religion, incorporating Catholic rituals and Saints in their ceremonies.

Why mention all this? Because the Vodun priest in many ways functions as political boss, advisor, doctor and psychiatrist for his people, and therefore Vodun supports and controls the vast majority of the Haiti population. If a hurricane or an earthquake kills a priest and destroys his houmfor, the center of social guidance and control are wiped out, leaving the peasants leaderless, intensifying their trauma and retarding their healing 'retribalization'. On the other hand, for any medical and mental health group trying to work with the peasants and multiply their healing effectiveness in enduring ways, they are well advised to form a respectful collaboration with their local Vodun priests and work with them. These priests, often sophisticated and smart about collaboration, will 'treat' disaster victims in their area, but also know their limit, and welcome having clinics to refer out to when a case is beyond their capacity. They like to get credit for being able to refer. And, when the medical clinic completes its acute care, the doctors can refer the peasant back to his local community and Vodun priest. Hospitals and local clinics are rare even if not collapsed, but Vodun priest are everywhere.

When I was a Yale anthropologist and a naïve premed, I practiced my brand of medicine in Haiti because peasants came to me for help. Once I made the mistake of trying to treat a burn case without realizing he was under the care of a Priest, and I got in big trouble. Later, he took me aside, explained how things work in Haiti, and we got our signals straight. When I apologized and shaped up, he became a great friend and collaborative guide for me. It took some work to convince the IMC doctors of the utility and wisdom of actually collaborating with Vodun priests. Most were middle class, and either Catholic or protestant. Some were still in touch with their peasant and religious roots, while others were uncomfortable or even alienated from their family background. Once the doctors and nurses thought it through, they became adept at utilizing their own internal cultural resources. 'Any port in a storm' I heard one doctor saying to a nurse. Though in truth they found it still much easier to collaborate with Catholic and Protestant institutions. 
One evening, after a little medicinal Barbancout rhum, I decided to tell my version of Haitian history to explain why Voodoo was so important to the peasants. What follows opened a few medical eyes.

\section{Usefulness of historical perspective}

Haiti was once a lush tropical paradise called the Pearl of the Antilles, with beautiful forested mountains and rich alluvial plains--the crown jewel among France's prosperous colonies. Her plantations devoured vast numbers of slaves, many dying on slave ships even before reaching their harsh new world. To subdue them, French slave masters broke and scattered their families and tribes, rendering them totally dependent on their overseers.

But the slave masters made one fatal mistake. They allowed the slaves to hold religious ceremonies in the dead of night. From shared African roots, ancient and powerful Vodun Loa, their ancient Rada gods, cool and wise, appeared during ceremonies, biding their time. Through spirit possession, these Gods took over the consciousness of the downtrodden slaves, one at time during ceremonies, boldly speaking of ancestor worship, community and hope. Slowly, the new world religion of Voodoo, or Vodun, was born and spread among the plantations throughout Haiti. Led by powerful priests called Houngans, Voodoo became a healing and unifying force for the slaves during their darkest hours.

Even so, life on the plantations became more unbearable near the end of the 18th century. Suddenly, hot new Loa, Petro gods, began possessing slaves, demanding blood and revenge. Out of this Voodoo hotbed, a volcanic eruption shook Haiti, as these bloodthirsty gods and their angry Houngans ignited rebellion across the land. After thirteen years of guerilla war and 20,000 troops sent by Napoleon, Haiti's slaves stunned Europe with a military victory-becoming the only slave colony to win freedom, making Haiti the second country after the United States to gain independence in the Western Hemisphere.

From this glorious moment in 1804, Haiti has experienced a tragic decline. Her succession of governments, often self-serving or corrupt until the most recent, have allowed her people to plunge into abject malaria-ridden poverty. With virtually no roads or phones, no trains or power, Haiti's hearty but illiterate peasants barely survive. Stripping the mountains of trees for charcoal, the country now suffers dangerous erosion, flooding and mudslides. Thousands have been buried alive during tropical storms and hurricanes, and 150,000 died in this most recent earthquake. Though the plains are still fertile, overpopulation and excessive land division have left the peasants that remain eking out their existence. With few doctors and the highest infant mortality rate in the Western hemisphere, peasant life is so difficult that hundreds of boat people try to escape to the United States each year--abandoning their beloved island of blood and bougainvilleas. Drug traffickers, dealing especially in the white snow of cocaine, exploit Haiti. Against this seemingly hopeless backdrop, the Haitian peasants live with hearty enduring enthusiasm--their social fabric knit together by their predominant religion, Vodun, with their priests providing spiritual direction, compelling social organization, and medical-psychological consultation-just as in the days of the Haitian Revolution. 
As if the earthquake were not enough of a challenge, shortly after returning to the US, as I was reviewing my field notes and diary, Hurricane Thomas roared through Haiti, followed by the Cholera epidemic brought to Haiti by an unwitting United Nations Nepalese caretaker soon taking a huge toll. Even so, Haitians are an amazing people, true survivors, and yet I worry there are limits to the suffering they can endure. I hope the world relief effort begins to take firmer hold very soon.

\section{Conclusion}

In conclusion, I hope this first-hand description of front line clinical work in Haiti illustrates many of the essential clinical and training principles of psychiatric trauma work and gives an immediate sense of the experience of care giving under dire circumstances. Perhaps the most surprising thing I learned during my work in Haiti is the fact that, despite the vast number of people traumatized, the diagnosis of Post-Traumatic Stress Disorder is a low-percentage outcome, perhaps around $13 \%$. And by using the approaches utilized by the International Medical Corp, reflected in my lectures and clinical practice, that percentage can be drastically reduced. Prevention of chronic medical or psychiatric disease is perhaps one of the most important outcomes of this work. While Acute Traumatic Stress is common, early medical and psychiatric intervention can prevent that state moving on into chronic post-traumatic stress disorder. Given how resilient people are, especially the Haitian people, this approach really works.

At the same time, people who are vulnerable or have chronic pre-existing conditions come to these new clinics to receive help for the first time, or because they are cut off from their physicians or treating institutions. Providing care for them is expectable and essential, but follow-up is difficult because of the lack of facilities or local medical care. Recognizing this dilemma, even for the most hesitant or biased physician, leads in a practical sense to the strategy of using any surviving community leaders or healers. In Haiti, this means turning to Vodun Houngans (Priests), both for referrals and follow-up. They are the major resource in the community for healing, collaboration, and 'retribalization' (re-establishing community social structure. To a smaller degree, in other instances, one can turn to the Catholic, Episcopal or Pentecostal Churches. If medical groups try to 'go it alone' by trying to rely solely on doctor or hospital referral, they discover that resources are often scarce. Acute care is the major focus, per necessity, and rightly so. Acute care and prevention are the major goals. But community healing an essential reintegration are and enduring part of the solution.

\section{Author details}

\section{Kent Ravenscroft}

Address all correspondence to: kent.ravenscroft@gmail.com

Psychiatry, Georgetown and George Washington Medical Schools, Washington, DC, USA 


\section{References}

[1] The Mw 7.0 Haiti Earthquake of January 12, 2010 USGS/EERI Advanced Reconnaissance Team Report V.1.1 February 23, 2010

[2] Psychiatric Consultation to the Child with Acute Physical Trauma, in Annual Progress in Child Psychiatry and Child Development, Ed. By Stella Chess, M.D. and Alexander Thomas, M.D., Bruner-Mazel, New York, page 448-461, 1983

[3] Different Faces of Trauma in a Three and a Four Year Old Girl, the International Institute of Object Relations Therapy, Summer Institute on Clinical Work Across Generations and Modalities, July 14-20, 2002

[4] Haiti Fare Well (book) Kent Ravenscroft, MD 2011 Lulu.com ISBN 978-1-257-03187-0

[5] Disaster Psychiatry in Haiti: Training Haitian Medical Professionals (E-book) Kent Ravenscroft, MD 2013 International Psychotherapy Institute (E-Book Division)

[6] Body Sharing: The Drug War, the CIA, and Haitian Voodoo by Kent Ravenscroft 2012 ISBN 978-0-557-29995-9 Lulu.com

[7] The Divine Horseman: The Living Gods of Haiti (book)(film) Maya Deren Amazon.com

[8] Secrets of Voodoo Milo Rigaud Amazon.com

[9] Earthquake Psychiatric Relief Kent Ravenscroft, MD Images in Psychiatry, American Journal of Psychiatry, Sept 10, 2010

[10] Experiences in Haiti Kent Ravenscroft, MD Washington Psychiatrist, Spring Issue 2013 Washington Psychiatric Society Bulletin

[11] Helping in Haiti Kent Ravenscroft, MD IPI Bulletin, Vol. 13 Number 1 Spring 2010 International Psychotherapy Institute

[12] My experience in Haiti: a brief report Kent Ravenscroft, MD World Psychiatry, volume 3, October, 2010 
